\title{
Kisspeptin-Gpr54 Signaling at the GnRH Neuron Is Necessary for Negative Feedback Regulation of Luteinizing Hormone Secretion in Female Mice
}

\author{
Shel-Hwa Yeo Jenny Clarkson Allan E. Herbison \\ Centre for Neuroendocrinology, Department of Physiology, School of Medical Sciences, University of Otago, \\ Dunedin, New Zealand
}

\begin{abstract}
Key Words
Gonadotropin-releasing hormone · Estradiol · Kisspeptin ·

Gpr54 · Estrogen feedback · Luteinizing hormone
\end{abstract}

\begin{abstract}
Kisspeptin-Gpr54 signaling is critical for regulating the activity of gonadotropin-releasing hormone $(\mathrm{GnRH})$ neurons in mammals. Previous studies have shown that the negative feedback mechanism is disrupted in global Gpr54-null mutants. The present investigation aimed to determine (1) if a lack of cyclical estrogen exposure of the $\mathrm{GnRH}$ neuronal network in the life-long hypogonadotropic Gpr54-null mice contributed to their failed negative feedback mechanism and (2) the cellular location of disrupted kisspeptin-Gpr54 signaling. Plasma luteinizing hormone (LH) concentrations were determined in individual adult female mice when intact, following ovariectomy (OVX) and in response to an acute injection of $17 \beta$-estradiol (E2). Control mice exhibited a characteristic rise in LH after OVX that was suppressed by acute E2. Global Gpr54-null mice failed to exhibit any postOVX increase in LH or response to E2. Adult female global Gpr54-null mice given a cyclical regimen of estradiol for three cycles prior to OVX also failed to exhibit any post-OVX increase in LH or response to E2. To address whether Gpr54 signaling at the GnRH neuron itself was necessary for the failed response to OVX in global Gpr54-null animals, adult female mice with a GnRH neuron-selective deletion of Gpr54
\end{abstract}

were examined. These mice also failed to exhibit any postOVX increase in LH or response to E2. These experiments demonstrate defective negative feedback in global Gpr54null mice that cannot be attributed to a lack of prior exposure of the $\mathrm{GnRH}$ neuronal network to cyclical estradiol. The absence of negative feedback in GnRH neuron-selective Gpr54-null mice demonstrates the necessity of direct kisspeptin signaling at the $\mathrm{GnRH}$ neuron for this mechanism to occur.

(c) 2014 S. Karger AG, Basel

\section{Introduction}

Reproductive function is critically dependent upon the gonadotropin-releasing hormone $(\mathrm{GnRH})$ neurons that represent the final output cells of a complex neuronal network integrating multiple internal and external signals [1]. Estradiol is one such internal factor that acts as a potent feedback signal within the hypothalamic-pituitarygonadal axis exerting both positive and negative feedback actions on GnRH secretion [2-5]. Considerable evidence documents that estradiol suppresses the activity of both the GnRH neurons and pituitary gonadotrophs to restrain pulsatile luteinizing hormone (LH) secretion for the majority of the ovarian cycle [6]. However, the cellular mechanisms underlying this negative feedback mechanism in the brain are poorly understood at present. Sev-

\section{KARGER}

E-Mail karger@karger.com

www.karger.com/nen
(C) 2014 S. Karger AG, Basel

0028-3835/14/1003-0191\$39.50/0
Prof. Allan E. Herbison

Centre for Neuroendocrinology, Department of Physiology

School of Medical Sciences, University of Otago

PO Box 913, Dunedin 9054 (New Zealand)

E-Mail allan.herbison@otago.ac.nz 
eral studies indicate that estradiol uses classical and nonclassical signaling mechanisms acting both directly and indirectly at GnRH neurons to suppress their activity [712].

Kisspeptin neurons signaling through Gpr54 (also known as Kiss1r) play an important role in the regulation of GnRH neurons and fertility $[13,14]$. There is now general agreement that kisspeptin neurons located in the preoptic area are essential for the estrogen-positive feedback mechanism generating the preovulatory LH surge [1517]. It is less clear how kisspeptin neurons may be involved in the negative feedback mechanism. As estrogen suppresses Kiss 1 mRNA expression within the arcuate nucleus (ARN), it was originally suggested that these cells may be involved in the estrogen-negative feedback mechanism [18]. However, electrophysiological studies examining ARN kisspeptin neurons in brain slices have not found evidence to support this role [19-21]. Similarly, although the selective ablation of almost all ARN kisspeptin neurons in adult rats reduces the increment in $\mathrm{LH}$ secretion following ovariectomy (OVX), estradiol is still able to suppress LH release in these animals [22]. Nevertheless, genetic studies examining the effects of gonadectomy on LH secretion in different global Gpr54 knockout mouse models have consistently shown that the LH rise following gonadectomy is blunted or abolished in the absence of Gpr54 [23-25].

Aside from potential discrepancies between different Gpr54 knockout mouse models (for example, see [23, 26]), there is a major ambiguity in interpreting data from adult mice that exhibit profound hypogonadotropic hypogonadism. As Gpr54-null mice have never gone through puberty or had normal estrous cycles, the adult GnRH neuronal network (i.e. the GnRH neurons and associated neuronal afferents and glial cells) will not have experienced cycles of estradiol exposure. For example, the normal fluctuations in plasma estradiol that occur across the estrous cycle modulate the expression of ion channels expressed by kisspeptin neurons [27, 28]. The life-long absence of these cyclical neuromodulatory actions may impact on the ability of the network as a whole to respond to gonadectomy and gonadal steroid manipulations in the adult. A further concern in interpreting results from global Gpr54 knockouts is that the pituitary gland plays an important role in the estrogen-negative feedback mechanism [29], and there is accruing evidence for a small role of kisspeptin-Gpr54 signaling in this tissue $[14,30,31]$. As such, it is not possible at present to ascribe the deficit in negative feedback in global Gpr54null mice to only the GnRH neuronal network.
In the present investigation, we examined the effect of ovariectomy and acute estradiol replacement upon LH secretion in the Colledge Gpr54-null mutant mouse line $[13,32]$. To assess whether defects in the negative feedback of Gpr54-null mice arise from a $\mathrm{GnRH}$ neuronal network that has never been exposed to fluctuating estradiol levels, we treated adult control and null mice with cycles of estradiol exposure before assessing negative feedback. Prior studies have shown that this cyclical pattern of estrogen exposure, which most closely mimics the normal cyclical fluctuations in estradiol, restores synaptic plasticity and function to hippocampal neuronal networks [33]. Finally, to address the key location of kisspeptin-Gpr54 signaling required for estrogen-negative feedback, we examined a new mouse model in which Gpr54 is deleted selectively from GnRH neurons [14].

\section{Materials and Methods}

\section{Animals}

Adult female Gpr54-null (129S6/Sv/Ev [13]) and GnRH$\mathrm{Cre}^{+/-} / \mathrm{Gpr} 54^{\text {flox/flox }}(\mathrm{C} 57 \mathrm{BL} 6$ [14]) mice as well as their control littermates (aged 3-5 months) were housed under a 12-hour light/ dark cycle (lights on at 06:00 and off at 18:00) and given ad libitum access to food and water. Genotypes of the transgenic animals were verified by PCR. All experimental protocols were performed under the authority of the University of Otago Animal Ethics Committee.

\section{Experiment 1: Estrogen-Negative Feedback in Female}

\section{Gpr54-Null Mice}

A well-established acute $17 \beta$-estradiol (E2)-negative feedback regimen was used in all studies [11, 34, 35]. Adult female Gpr54null and control wild-type $129 \mathrm{~S} 6 / \mathrm{Sv} / \mathrm{Ev}$ mice $(\mathrm{n}=7$ per group) were anesthetized with a cocktail of ketamine $(75 \mathrm{mg} / \mathrm{kg}$ body weight) and Domitor ( $0.5 \mathrm{mg} / \mathrm{kg}$ body weight), a tail tip blood sample was collected, and the animals were ovariectomized bilaterally. After surgery, mice were given an Antisedan injection $(1.0 \mathrm{mg} / \mathrm{kg}$ body weight, s.c.) to reverse the sedative effects of Domitor. One week later, a second tail tip blood sample was obtained immediately after the animals had been anesthetized. Two days after recovery from anesthesia, the animals received an E2 injection $(1 \mu \mathrm{g} / 20 \mathrm{~g}$ body weight, s.c.) in the morning at 09:00. The animals were decapitated $3 \mathrm{~h}$ later and blood was collected from the trunk. Plasma was separated by centrifugation and plasma samples were stored at $-20^{\circ} \mathrm{C}$ until assayed for LH by radioimmunoassay.

Experiment 2: Estrogen-Negative Feedback in Female Gpr54-Null Animals following Cyclical Estrogen Exposure

To address whether the estrogen-negative feedback mechanism requires prior activation of estrogen-sensitive brain circuitry, adult female Gpr54-null and control mice ( $\mathrm{n}=6$ per group) were anesthetized with ketamine and Domitor as above, the first tail tip blood sample was collected, and then they were ovariectomized. At the time of OVX, mice were implanted s.c. with an estradiol Silastic capsule ( $1 \mu \mathrm{g}$ E2/20 g body weight; [36]) that generates negative 
feedback levels of LH secretion in normal mice [37]. Mice were then given one injection of estradiol benzoate $(1 \mu \mathrm{g} / 20 \mathrm{~g}$ body weight, s.c.) every 4 days for 3 cycles to simulate the follicular phase increment in estradiol levels that generate positive feedback and an LH surge [26]. This regimen was modified for mice from the work of Conrad et al. [33]. At the end of the artificial estrogen cycles, the Silastic capsules were removed and the mice left for 2 weeks (to allow the full OVX state to occur) before a third blood sample was obtained. Two days later, the animals received an E2 injection ( $1 \mu \mathrm{g} / 20 \mathrm{~g}$ body weight, s.c.) in the morning, and $3 \mathrm{~h}$ later, the mice were administered a lethal dose of pentobarbital $(3 \mathrm{mg} / 100 \mu \mathrm{l})$ and a final blood sample was collected from the inferior vena cava.

\section{Experiment 3: Estrogen-Negative Feedback in Female}

GnRH-Cre/Gpr54 flox/flox Mice

To examine whether the estrogen-negative feedback mechanism is dependent upon Gpr54 expression in GnRH neurons alone, adult female GnRH-Cre ${ }^{+/-} / \mathrm{Gpr} 54^{\text {flox/flox }}(\mathrm{n}=7$ per group) and control (GnRH-Cre ${ }^{-/-} / \mathrm{Gpr} 54^{\text {flox/flox }} \mathrm{n}=6$ per group) mice were anesthetized with $2 \%$ halothane inhalation, blood collected from the tail tip, and then ovariectomized. Two weeks after OVX, the animals were anesthetized and a second blood sample was obtained. Two days later, the animals received an E2 injection ( $1 \mu \mathrm{g} / 20 \mathrm{~g}$ body weight, s.c.) in the morning, and $3 \mathrm{~h}$ later, the mice were administered a lethal dose of pentobarbital $(3 \mathrm{mg} / 100 \mu \mathrm{l})$ and a final blood sample was collected from the inferior vena cava.

Experiment 4: Pituitary Gland GnRH Stimulation Test in Female GnRH-Cre/Gpr54 flox/flox Mice

To establish if the anterior pituitary gonadotrophs of control (GnRH-Cre ${ }^{-/-} / \mathrm{Gpr} 54^{\text {flox/flox }}$ ) and mutant (GnRH-Cre ${ }^{+/-}$/ Gpr54 flox/flox $) \mathrm{GnRH}$ neuron-selective mice were equally responsive to $\mathrm{GnRH}$, we performed a pituitary GnRH stimulation test. Adult female GnRH-Cre/Gpr54 $4^{\text {flox/flox }}(\mathrm{n}=4)$ and control mice $\left(\mathrm{GnRH}-\mathrm{Cre}^{-/-} / \mathrm{Gpr} 54^{\text {flox/flox; }} \mathrm{n}=6\right)$ were anesthetized with $2 \%$ halothane and the first tail blood sample was obtained. All animals were then administered GnRH (Bachem, Bubendorf, Switzerland) dissolved in phosphate-buffered saline $(200 \mathrm{ng} / \mathrm{kg}$ in $100 \mu \mathrm{l}$ saline, s.c.). The animals were decapitated $10 \mathrm{~min}$ after $\mathrm{GnRH}$ administration and trunk blood was collected. Plasma was separated by centrifugation and plasma samples were stored at $-20^{\circ} \mathrm{C}$ until radioimmunoassay for $\mathrm{LH}$.

\section{Radioimmunoassay for Plasma LH}

Quantification of plasma LH levels was performed with radioimmunoassay using the anti-rabbit LH antiserum (AFP-240580) and mouse LH reference preparation (AFP-5306A) provided by Dr. A.F. Parlow (National Hormone and Peptide Program, Torrance, Calif., USA). All plasma samples were assayed in duplicates with a sensitivity of $0.2 \mathrm{ng} / \mathrm{ml}$. The intra-assay coefficient of variation for the assay was $16.5 \%$ for experiment $1,9.9 \%$ for experiment $2,6.2 \%$ for experiment 3 , and $7.2 \%$ for the pituitary stimulation test. The inter-assay coefficient of variation for all the assays was $14.8 \%$.

\section{Statistical Analysis}

Statistical analyses were performed with two-way repeatedmeasures ANOVA (genotype vs. treatment) followed by HolmSidak's multiple-comparison tests to determine statistical differ-

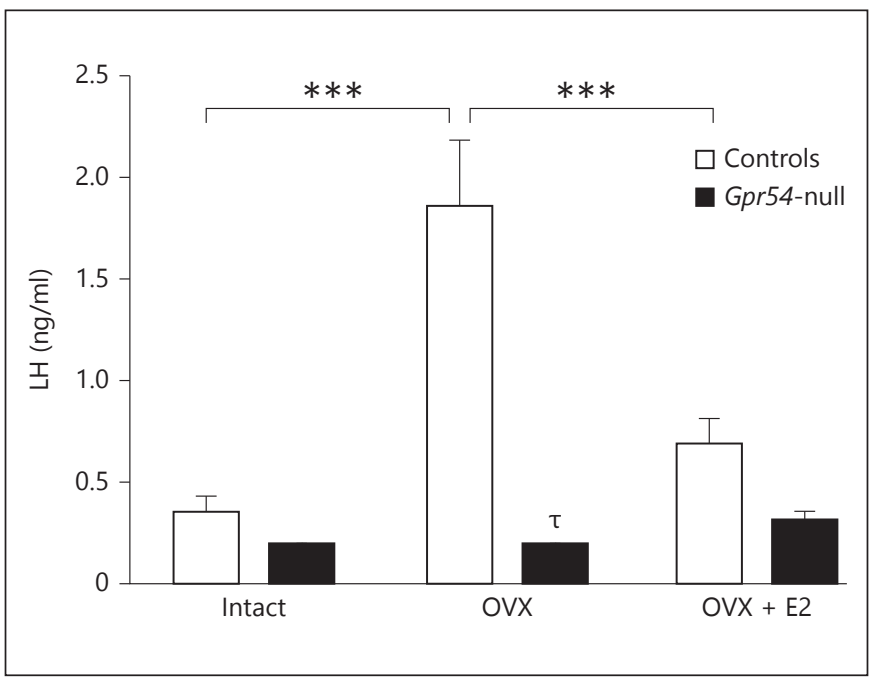

Fig. 1. Estrogen-negative feedback profiles in control and global Gpr54-null animals. Control mice ( $\mathrm{n}=7$; open bars) displayed a normal negative feedback profile, while Gpr54-null mice ( $\mathrm{n}=7$; solid bars) did not respond to $\operatorname{OVX}(\tau, \mathrm{p}<0.001$, compared with control values) or acute estradiol replacement. ${ }^{* * *} \mathrm{p}<0.001$; twoway repeated-measures ANOVA followed by Holm-Sidak's multiple comparison tests.

ences in LH levels between wild-type and knockout animals under different treatments (intact, OVX, OVX and E2 replacement) as well as significant changes in LH levels after treatments within each group. For the pituitary stimulation test, a nonparametric ANOVA (Kruskal-Wallis) and post hoc Dunn's multiple-comparison tests were performed due to the low number of GnRH-Cre/ Gpr54 animals $(n \leq 6)$ to assess the significant changes in LH levels upon stimulation. Data are presented as means \pm SEM.

\section{Results}

\section{Experiment 1: Estrogen-Negative Feedback in Female Gpr54-Null Mice}

To examine the necessity of Gpr54 signaling in the estrogen-negative feedback mechanism, Gpr54-null $(\mathrm{n}=7)$ and control $(n=7)$ mice were tested with an established acute estrogen-negative feedback protocol. Control wildtype littermates showed significantly elevated LH levels after OVX $(0.4 \pm 0.1$ vs. $1.9 \pm 0.4 \mathrm{ng} / \mathrm{ml} ; \mathrm{p}<0.001)$, and these were significantly reduced $3 \mathrm{~h}$ after E2 administration $(0.7 \pm 0.1 \mathrm{ng} / \mathrm{ml} ; \mathrm{p}<0.001$; fig. 1$)$. In Gpr54-null mice, basal levels of $\mathrm{LH}(0.2 \pm 0.1 \mathrm{ng} / \mathrm{ml})$ were not significantly different compared with controls $(0.4 \pm 0.1 \mathrm{ng} /$ $\mathrm{ml})$, but neither OVX $(0.2 \pm 0.4 \mathrm{ng} / \mathrm{ml})$ nor E2 replacement $(0.3 \pm 0.1 \mathrm{ng} / \mathrm{ml})$ were found to have any significant effect on LH levels ( $p>0.05$; fig. 1). 


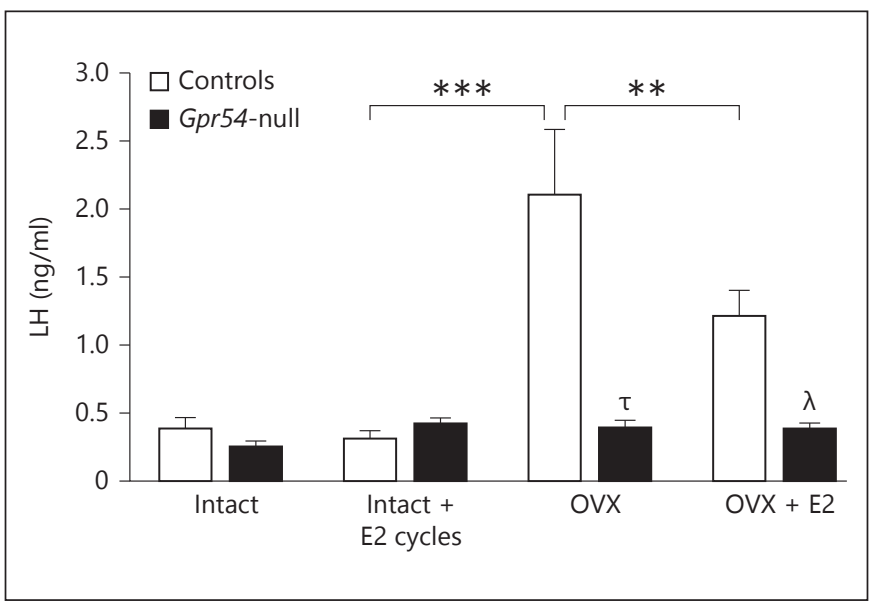

Fig. 2. Estrogen-negative feedback profiles in control and global Gpr54-null animals given prior estradiol cycling. Intact mice of both genotypes were treated with three 4-day estradiol (E2) cycles before testing the negative feedback mechanism. Control mice ( $n=6$; open bars) exhibited normal suppressed basal LH levels before and after the E2 cycling and then showed a normal negative feedback profile of LH secretion (*** $\mathrm{p}<0.001$; $\left.{ }^{* *} \mathrm{p}<0.01\right)$. The LH levels in the Gpr54-null mice ( $\mathrm{n}=6$; solid bars) did not change in response to any treatment and were significantly reduced compared with $\operatorname{OVX}(\tau, \mathrm{p}<0.001)$ and OVX plus E2 $(\lambda, \mathrm{p}<0.05)$ levels in controls. Two-way repeated-measures ANOVA followed by Holm-Sidak's multiple comparison tests.

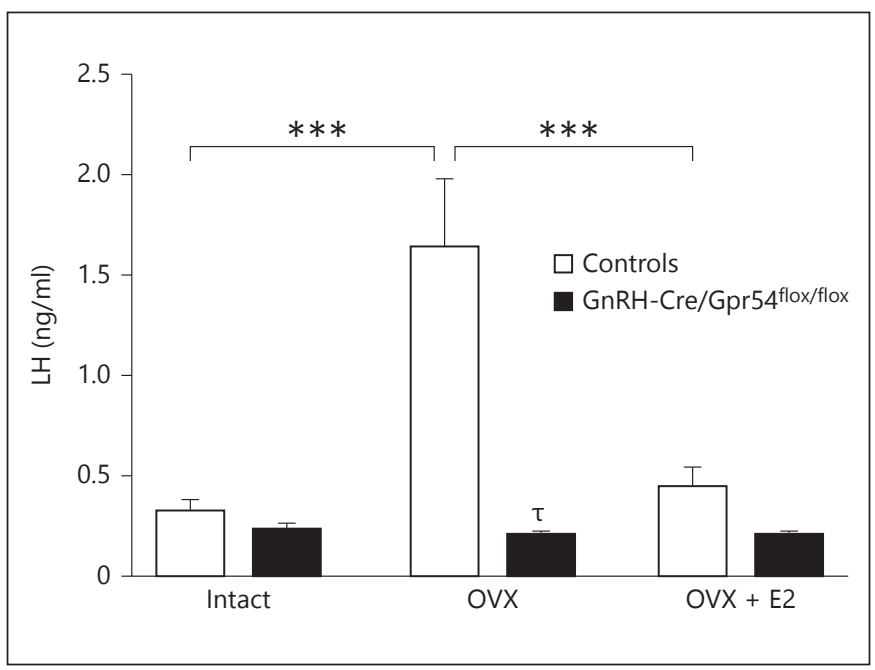

Fig. 3. Estrogen-negative feedback profiles in control and mutant GnRH neuron-specific Gpr54-deleted mice. Control mice $(n=6$; open bars) exhibited a normal negative feedback response with an increase in LH after OVX and a decrease in response to acute estradiol (E2) treatment. The GnRH-Cre ${ }^{+/-} / \mathrm{Gpr} 54^{\text {flox/flox }}$ mice $(\mathrm{n}=$ 7; solid bars) exhibited low LH levels that did not change with treatment ( $\tau, \mathrm{p}<0.001$, compared with control values). ${ }^{* * *} \mathrm{p}<$ 0.001; two-way repeated-measures ANOVA followed by HolmSidak's multiple comparison tests.
Experiment 2: Estrogen-Negative Feedback in Female Gpr54-Null Animals following Cyclical Estrogen

Exposure

Basal concentrations of $\mathrm{LH}$ were not different between Gpr54-null $(\mathrm{n}=6)$ and littermate control mice $(\mathrm{n}=6)$ and also not altered by the three 4-day cycles of E2 (fig. 2). Control mice responded normally to the gonadectomyacute negative feedback regimen, exhibiting significantly elevated LH levels following OVX $(2.1 \pm 0.5 \mathrm{ng} / \mathrm{ml} ; \mathrm{p}<$ $0.001)$ that were then decreased by E2 $(1.2 \pm 0.2 \mathrm{ng} / \mathrm{ml}$; $\mathrm{p}<0.001$; fig. 2). In contrast, Gpr54-null mice continued to show no $\mathrm{LH}$ response to OVX or E2 administration (basal after E2 cycling: $0.3 \pm 0.1 \mathrm{ng} / \mathrm{ml}$; OVX: $0.4 \pm 0.1 \mathrm{ng} /$ $\mathrm{ml} ; 3 \mathrm{~h}$ after E2: $0.4 \pm 0.1 \mathrm{ng} / \mathrm{ml}$; fig. 2).

\section{Experiment 3: Estrogen-Negative Feedback in Female} GnRH-Cre/Gpr54flox/flox Mice

The standard acute E2 feedback regimen was used to examine the effects of OVX and E2 replacement on $\mathrm{LH}$ secretion in mice with a $\mathrm{GnRH}$ neuron-selective deletion of Gpr54. Control littermate mice (GnRH-Cre ${ }^{-/-}$/ Gpr54 flox/flox; $n=6$ ) exhibited the normal profile of LH secretion in this regimen with a significant elevation following OVX $(1.6 \pm 0.4 \mathrm{ng} / \mathrm{ml} ; \mathrm{p}<0.001)$ and subsequent suppression by E2 $(0.5 \pm 0.2 \mathrm{ng} / \mathrm{ml} ; \mathrm{p}<0.001$; fig. 3$)$. Mutant GnRH-Cre ${ }^{+/-} / \mathrm{Gpr} 54^{\text {flox/flox }}$ mice $(\mathrm{n}=7)$ had low basal LH levels $(0.2 \pm 0.1 \mathrm{ng} / \mathrm{ml})$ that were not significantly different from controls $(0.2 \pm 0.1 \mathrm{ng} / \mathrm{ml})$ but failed to respond to OVX or E2 treatment (fig. 3).

\section{Experiment 4: Pituitary Gland GnRH Stimulation}

Test in Female GnRH-Cre/Gpr54 flox/flox Mice

To confirm that the failure of GnRH-Cre/Gpr5 $4^{\text {flox/flox }}$ mice to exhibit a post-OVX LH rise was not due to an abnormality at the level of the anterior pituitary gland, a GnRH stimulation test was performed in a group of control $(\mathrm{n}=6)$ and GnRH-Cre ${ }^{+/-} / \mathrm{Gpr} 54^{\text {flox/flox }}(\mathrm{n}=4)$ mice. Basal LH levels were similarly low in both groups $(0.2 \pm$ $0.1 \mathrm{ng} / \mathrm{ml}$ ) and exogenous $\mathrm{GnRH}$ significantly elevated LH levels in both genotypes ( $1.0 \pm 0.1$ vs. $1.3 \pm 0.1 \mathrm{ng} / \mathrm{ml}$; fig. 4). The increment in LH was not different between the two genotypes.

\section{Discussion}

We report here that, as in other global Gpr54-null mouse lines [23-25], OVX of the Colledge Gpr54-null strain does not result in an increment in LH secretion. Furthermore, acute E2 treatment does not impact further 


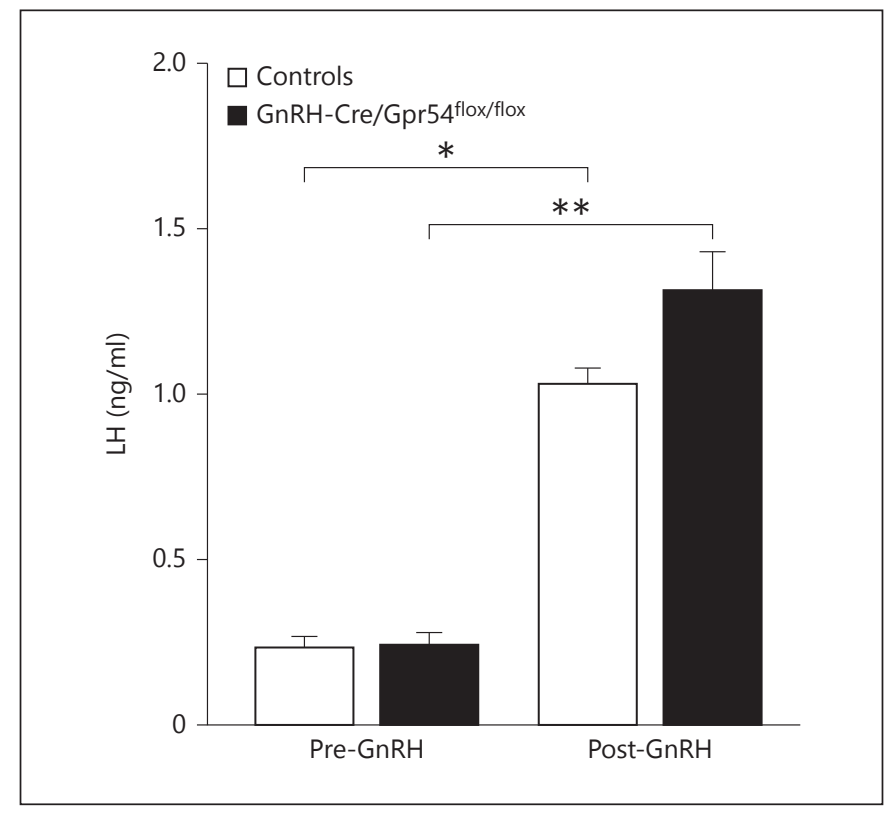

Fig. 4. Pituitary gland responsiveness to $\mathrm{GnRH}$ in control and mutant GnRH neuron-specific Gpr54-deleted mice. Exogenous $\mathrm{GnRH}$ administration significantly elevated LH levels both in control ( $\mathrm{n}=6$; open bars) and GnRH-Cre ${ }^{+/-} / \mathrm{Gpr} 54^{\text {flox/flox }}$ mice $(\mathrm{n}=4$; solid bars). No difference in the increment in LH was found between the genotypes. ${ }^{* *} \mathrm{p}<0.01$ and $* \mathrm{p}<0.05$; nonparametric ANOVA Kruskal-Wallis with Dunn's post hoc tests.

on the already low levels of LH in these mice. This demonstrates the necessity of Gpr54 signaling within the body for normal negative feedback to occur. We had speculated that this may result from a deficit in the normal cyclical estrogen exposure of the GnRH neuronal network in Gpr54 mutants. Accordingly, we employed a paradigm in which adult mice were exposed to estrogen in a cyclical manner for 2 weeks before evaluating their negative feedback mechanism. However, despite this prior exposure to estradiol, Gpr54-null female mice remained unable to generate a normal LH response profile to OVX or E2 replacement. We also examined here whether the deficit in negative feedback could be ascribed specifically to Gpr54 signaling at the GnRH neuron as opposed to other tissues such as the pituitary gland. We demonstrate that it is kisspeptin-Gpr54 signaling at the GnRH neuron itself that is necessary for the negative feedback mechanism.

Unlike the estrogen-positive feedback mechanism [1517], the role of kisspeptin-Gpr54 signaling in the estrogennegative feedback mechanism has been more difficult to ascertain. Several studies using Gpr54-null mice have found that there is no elevation in LH levels following castration [23-25], indicating that kisspeptin-Gpr54 signal- ing is likely to be needed for the negative feedback mechanism. Our own results, using repeated blood samples obtained from mice prior to and after OVX and then following acute estrogen treatment, show that the negative feedback mechanism is essentially absent in Gpr54-null mice. Because the post-OVX rise in LH failed to occur in the Gpr54-null mice, we speculated that estrogen-sensitive circuitry within the GnRH neuronal network may not be operational due to a prior complete absence of cyclical E2 exposure. However, we show that this is not the case as Gpr54-null mice treated in this manner were still unable to mount any type of LH response to the removal of ovarian steroids. Without an increment in LH secretion following OVX in the different Gpr54 mutant mouse lines, it is impossible to assess their suppressive response to estrogen.

We also show that the $\mathrm{LH}$ response to OVX is defective in GnRH neuron-specific Gpr54-deleted mice. This mouse line has a deletion of Gpr54 from all GnRH neurons and, possibly, a small population of cells located in the lateral septum and bed nucleus of the stria terminalis, but not elsewhere, including the pituitary gland and gonads [14]. The selective targeting of Gpr54 deletion to $\mathrm{GnRH}$ neurons in this mouse line is further defined here by showing that pituitary gonadotroph responses to $\mathrm{GnRH}$ are intact in GnRH-Cre ${ }^{+/-} / \mathrm{Gpr} 54^{\text {flox/lox }}$ mice. A recently published study by Novaira et al. [38] using a different GnRH neuron-targeted Gpr54-null mouse line has also shown such mice to exhibit an absence of the postOVX increment in LH secretion. Together, these studies indicate that it is a failure of kisspeptin signaling at the GnRH neuron itself, rather than other neurons [39] or reproductive tissues [30], which is responsible for the defective negative feedback mechanism.

There are at least two possible explanations for the absence of negative feedback in global or GnRH neuronspecific Gpr54-null mice. First, it is possible that E2-sensitive kisspeptin neurons are a critical transsynaptic component of the estrogen-negative feedback mechanism [5]. This possibility is supported by (1) a key role for neuronal ERa in acute negative feedback [11], (2) the presence of ERa in many kisspeptin neurons [15], and (3) the failure of prepubertal negative feedback in kisspeptin-targeted $\mathrm{ER} \alpha$ null mice [40]. As yet, the role of ER $\alpha$ in ARN kisspeptin neurons in adult estrogen-negative feedback has not been established, although the importance of ERa within ARN neurons more generally has recently been described [37]. The relationship of the well-documented estradiol suppression of ARN Kiss $1 \mathrm{mRNA}$ to adult estrogen-negative feedback is not known, although, like negative feedback on LH itself [9], it involves nonclassical ERa 
signaling [41, 42]. It was also shown that the selective ablation of ARN kisspeptin neurons in adult rats using saporin resulted in a reduced increment in LH secretion following OVX [22]. It remains unclear whether the reduced increment in LH after OVX represents a deficit in gonadal-steroid negative feedback or an inability of the $\mathrm{GnRH}$ neuronal network to generate pulsatile secretion. If E2-sensitive kisspeptin neurons do form part of the normal estrogen-negative feedback mechanism, then, presumably, the absence of this input throughout development results in the GnRH neuronal network 're-setting' to a low basal level of activity through a gonadal steroid-independent mechanism. Accordingly, the removal of gonadal steroids following OVX in adults no longer results in the same level of increased GnRH neuron activity and LH levels remain lower.

The second possibility is that GnRH neurons are so critically dependent upon kisspeptin signaling that they are essentially 'broken' in Gpr54 mutants and generally unable to function normally across a spectrum of activities, including negative feedback. Thus, the kisspeptin neuron does not need to be 'serially' involved in the estrogen-negative feedback pathway but may represent a critical 'parallel' input upon which several GnRH neuron behaviors are dependent [1]. This line of reasoning is supported by evidence in Gpr54-deleted mice for (1) abnormal levels of basal GnRH neuron electrical activity $[14],(2)$ the vastly reduced ability of the GnRH neuronal network to respond to a wide range of different neurotransmitters and neuropeptides [25], (3) the failure of the GnRH neuronal network to exhibit positive feedback [26], and (4) pulsatile GnRH/LH secretion [43]. In this context, it is interesting to note that the $10-20 \%$ of GnRH neurons identified by receptor profiling and electrophysiology that are not regulated by kisspeptin [1] appear insufficient to support most aspects of network function
$[14,24]$. In the absence of data demonstrating an unambiguous role for the ARN kisspeptin neurons in estrogen-negative feedback, the authors favor the second possibility of a parallel permissive role of kisspeptin to explain the ablated negative feedback response in Gpr54 mutants.

In summary, we report that exposure of the GnRH neuronal network in Gpr54-null mice to cyclical E2 fails to resurrect the estrogen-negative feedback mechanism. This implies that defective negative feedback in these mice is more fundamental than the adult absence of E2mediated plasticity within the network. It remains possible that treatment of Gpr54-null female mice with additional E2 at earlier times in development may have been effective in restoring feedback. Our subsequent experiments show that it is kisspeptin-Gpr54 signaling at the GnRH neuron that is necessary for negative feedback on gonadotropin secretion in adult female mice. This may represent a direct involvement of kisspeptin neurons in the estrogen-negative feedback mechanism or, more likely in our view, an indirect permissive action of kisspeptin inputs on GnRH neurons.

\section{Acknowledgements}

We thank Prof. Bill Colledge (University of Cambridge, UK) and Dr. A.F. Parlow (National Hormone and Peptide Program, USA) for contributing valuable reagents. This work was supported by the New Zealand Health Research Council and the New Zealand Ministry of Science and Innovation (J.C.; contract number UOOX0906).

\section{Disclosure Statement}

The authors have no conflicts of interest to disclose.

\section{References}

$>1$ Herbison AE: Physiology of the adult GnRH neuronal network; in Plant TM, Zeleznik AJ (eds): Knobil and Neill's Physiology of Reproduction. San Diego, Academic Press, 2014, pp 399-467.

-2 Christian CA, Moenter SM: The neurobiology of preovulatory and estradiol-induced gonadotropin-releasing hormone surges. Endocr Rev 2010;31:544-577.

- 3 Herbison AE: Estrogen positive feedback to gonadotropin-releasing hormone $(\mathrm{GnRH})$ neurons in the rodent: the case for the rostral periventricular area of the third ven- tricle (RP3V). Brain Res Rev 2008;57:277287.

-4 Petersen SL, Ottem EN, Carpenter CD: Direct and indirect regulation of gonadotropin-releasing hormone neurons by estradiol. Biol Reprod 2003;69:1771-1778.

5 Herbison AE: Multimodal influence of estrogen upon gonadotropin-releasing hormone neurons. Endocr Rev 1998;19:302-330.

6 Freeman MC: Neuroendocrine control of the ovarian cycle of the rat; in Neill JD (ed): Knobil and Neill's Physiology of Reproduction. San Diego, Academic Press, 2006, pp 2327-2388.
Herbison AE: Rapid actions of oestrogen on gonadotropin-releasing hormone neurons; from fantasy to physiology? J Physiol 2009; 587:5025-5030.

8 Moenter SM, Chu Z: Rapid nongenomic effects of oestradiol on gonadotrophin-releasing hormone neurones. J Neuroendocrinol 2012;24:117-121.

-9 Glidewell-Kenney C, Hurley LA, Pfaff L, Weiss J, Levine JE, Jameson JL: Nonclassical estrogen receptor alpha signaling mediates negative feedback in the female mouse reproductive axis. Proc Natl Acad Sci U S A 2007;104:8173-8177. 
$\checkmark 10$ Cheong RY, Kwakowsky A, Barad Z, Porteous R, Herbison AE, Abraham IM: Estradiol acts directly and indirectly on multiple signaling pathways to phosphorylate cAMP-response element binding protein in GnRH neurons. Endocrinology 2012;153:3792-3803.

-11 Cheong RY, Porteous R, Chambon P, Abraham IA, Herbison AE: Effects of neuron-specific estrogen receptor (ER) $\alpha$ and ER $\beta$ deletion on the acute estrogen negative feedback mechanism in adult female mice. Endocrinology 2014;155:1418-1427.

12 Kwakowsky A, Herbison AE, Abraham IM: The role of camp response element-binding protein in estrogen negative feedback control of gonadotropin-releasing hormone neurons. J Neurosci 2012;32:11309-11317.

-13 Seminara SB, Messager S, Chatzidaki EE, Thresher RR, Acierno JS Jr, Shagoury JK, BoAbbas Y, Kuohung W, Schwinof KM, Hendrick AG, Zahn D, Dixon J, Kaiser UB, Slaugenhaupt SA, Gusella JF, O'Rahilly S, Carlton MB, Crowley WF Jr, Aparicio SA, Colledge $\mathrm{WH}$ : The GPR54 gene as a regulator of puberty. N Engl J Med 2003;349:1614-1627.

-14 Kirilov M, Clarkson J, Liu X, Roa J, Campos P, Porteous R, Schutz G, Herbison AE: Dependence of fertility on kisspeptin-Gpr54 signaling at the GnRH neuron. Nature Commun 2013;4:2492.

15 Smith JT: Kisspeptin signalling in the brain: steroid regulation in the rodent and ewe. Brain Res Rev 2008;57:288-298.

16 Clarkson J, Herbison AE: Oestrogen, kisspeptin, Gpr54 and the pre-ovulatory luteinising hormone surge. J Neuroendocrinol 2009; 21:305-311.

-17 Ohkura S, Uenoyama Y, Yamada S, Homma $\mathrm{T}$, Takase $\mathrm{K}$, Inoue $\mathrm{N}$, Maeda $\mathrm{K}$, Tsukamura $\mathrm{H}$ : Physiological role of metastin/kisspeptin in regulating gonadotropin-releasing hormone $(\mathrm{GnRH})$ secretion in female rats. Peptides 2009;30:49-56.

18 Popa SM, Clifton DK, Steiner RA: The role of kisspeptins and Gpr54 in the neuroendocrine regulation of reproduction. Annu Rev Physiol 2008;70:213-238.

-19 de Croft S, Piet R, Mayer C, Mai O, Boehm U, Herbison AE: Spontaneous kisspeptin neuron firing in the adult mouse reveals marked sex and brain region differences but no support for a direct role in negative feedback. Endocrinology 2012;153:5384-5393.

20 Ruka KA, Burger LL, Moenter SM: Regulation of arcuate neurons coexpressing kisspeptin, neurokinin $B$, and dynorphin by modulators of neurokinin 3 and $\kappa$-opioid receptors in adult male mice. Endocrinology 2013; 154:2761-2771.

- 21 Frazao R, Cravo RM, Donato J Jr, Ratra DV, Clegg DJ, Elmquist JK, Zigman JM, Williams KW, Elias CF: Shift in Kiss1 cell activity requires estrogen receptor alpha. J Neurosci 2013;33:2807-2820.
22 Mittelman-Smith MA, Williams H, Krajewski-Hall SJ, Lai J, Ciofi P, McMullen NT, Rance NE: Arcuate kisspeptin/neurokinin B/dynorphin (KNDy) neurons mediate the estrogen suppression of gonadotropin secretion and body weight. Endocrinology 2012;153:28002812.

23 Dungan HM, Gottsch ML, Zeng H, Gragerov A, Bergmann JE, Vassilatis DK, Clifton DK, Steiner RA: The role of kisspeptin-GPR54 signaling in the tonic regulation and surge release of gonadotropin-releasing hormone/ luteinizing hormone. J Neurosci 2007;27: 12088-12095.

24 Chan YM, Broder-Fingert S, Wong KM, Seminara SB: Kisspeptin/Gpr54-independent gonadotrophin-releasing hormone activity in Kiss1 and Gpr54 mutant mice. J Neuroendocrinol 2009;21:1015-1023.

25 Garcia-Galiano D, van Ingen Schenau D, Leon S, Krajnc-Franken MA, Manfredi-Lozano M, Romero-Ruiz A, Navarro VM, Gaytan F, van Noort PI, Pinilla L, Blomenrohr M, Tena-Sempere M: Kisspeptin signaling is indispensable for neurokinin B, but not glutamate, stimulation of gonadotropin secretion in mice. Endocrinology 2012;153:316-328.

26 Clarkson J, d'Anglemont de Tassigny X, Moreno AS, Colledge WH, Herbison AE: Kisspeptin-GPR54 signaling is essential for preovulatory gonadotropin-releasing hormone neuron activation and the luteinizing hormone surge. J Neurosci 2008;28:8691-8697.

27 Piet R, Boehm U, Herbison AE: Estrous cycle plasticity in the hyperpolarization-activated current ih is mediated by circulating $17 \beta$-estradiol in preoptic area kisspeptin neurons. J Neurosci 2013;33:10828-10839.

28 Campbell RE, Herbison AE: Gonadal steroid neuromodulation of developing and mature hypothalamic neuronal networks. Curr Opin Neurobiol 2014;29C:96-102.

29 Shupnik MA: Gonadal hormone feedback on pituitary gonadotropin genes. Trends Endocrinol Metab 1996;7:272-276.

30 Richard N, Corvaisier S, Camacho E, Kottler ML: Kiss-1 and Gpr54 at the pituitary level: overview and recent insights. Peptides 2009; 30:123-129.

- 31 Luque RM, Cordoba-Chacon J, Gahete MD, Navarro VM, Tena-Sempere M, Kineman RD, Castano JP: Kisspeptin regulates gonadotroph and somatotroph function in nonhuman primate pituitary via common and distinct signaling mechanisms. Endocrinology 2011;152:957-966.

32 Colledge WH: Transgenic mouse models to study Gpr54/kisspeptin physiology. Peptides 2009;30:34-41.
33 Conrad CD, McLaughlin KJ, Huynh TN, ElAshmawy M, Sparks M: Chronic stress and a cyclic regimen of estradiol administration separately facilitate spatial memory: relationship with hippocampal CA1 spine density and dendritic complexity. Behav Neurosci 2012; 126:142-156.

34 Abraham IM, Han SK, Todman MG, Korach KS, Herbison AE: Estrogen receptor beta mediates rapid estrogen actions on gonadotropin-releasing hormone neurons in vivo. J Neurosci 2003;23:5771-5777.

35 Campbell RE, Ducret E, Porteous R, Liu X, Herde MK, Wellerhaus K, Sonntag S, Willecke K, Herbison AE: Gap junctions between neuronal inputs but not gonadotropin-releasing hormone neurons control estrous cycles in the mouse. Endocrinology 2011;152:22902301.

36 Bronson FH: The regulation of luteinizing hormone secretion by estrogen: relationships among negative feedback, surge potential, and male stimulation in juvenile, peripubertal, and adult female mice. Endocrinology 1981;108:506-516.

37 Yeo SH, Herbison AE: Estrogen-negative feedback and estrous cyclicity are critically dependent upon estrogen receptor-alpha expression in the arcuate nucleus of adult female mice. Endocrinology 2014;155:29862995.

38 Novaira HJ, Sonko ML, Hoffman G, Koo Y, Ko C, Wolfe A, Radovick S: Disrupted kisspeptin signaling in GnRH neurons leads to hypogonadotrophic hypogonadism. Mol Endocrinol 2014;28:225-238.

-39 Pielecka-Fortuna J, Chu Z, Moenter SM: Kisspeptin acts directly and indirectly to increase gonadotropin-releasing hormone neuron activity and its effects are modulated by estradiol. Endocrinology 2008;149:1979-1986.

-40 Mayer C, Acosta-Martinez M, Dubois SL, Wolfe A, Radovick S, Boehm U, Levine JE: Timing and completion of puberty in female mice depend on estrogen receptor alpha-signaling in kisspeptin neurons. Proc Natl Acad Sci U S A 2010;107:22693-22698.

41 Smith JT, Cunningham MJ, Rissman EF, Clifton DK, Steiner RA: Regulation of Kiss1 gene expression in the brain of the female mouse. Endocrinology 2005; 146:3686-3692.

42 Gottsch ML, Navarro VM, Zhao Z, GlidewellKenney C, Weiss J, Jameson JL, Clifton DK, Levine JE, Steiner RA: Regulation of Kiss1 and dynorphin gene expression in the murine brain by classical and nonclassical estrogen receptor pathways. J Neurosci 2009;29:93909395.

43 Steyn FJ, Wan Y, Clarkson J, Veldhuis JD, Herbison AE, Chen C: Development of a methodology for and assessment of pulsatile luteinizing hormone secretion in juvenile and adult male mice. Endocrinology 2013;154: 4939-4945. 